Cadernos de Clio, Curitiba, n. $^{\circ}$ 2, 2011

\title{
BARKER, Juliet. Agincourt: o Rei, a Campanha, a Batalha. Rio de Janeiro: Record, 2009.
}

Guilherme Floriani Saccomori ${ }^{1}$

O livro Agincourt: O Rei, a Campanha, a Batalha da autora inglesa Juliet Barker foi publicado pela primeira vez na Inglaterra em 2005, pela editora Little Brown; foi traduzido para o português e publicado no Brasil em 2009 pela editora Record. Em uma vasta análise bibliográfica e de fontes, a autora descreve todo o processo, desde o início da Guerra dos Cem Anos até a batalha de Agincourt.

Juliet Barker nasceu em 1956 na cidade inglesa de Yorkshire, onde vive até hoje. É historiadora especialista em Idade Média e em literatura bibliográfica. Obteve seu doutorado em História Medieval em St Anne's College, Oxford e, em 1999, obteve um doutorado honorário de Letras pela Universidade de Bradford. Foi curadora e bibliotecária no Bronte Parsonage Museum² e também é membro da Real Sociedade de Literatura inglesa.

A batalha de Agincourt (1415) é um ponto da História muito estudado e que faz parte sem dúvida do imaginário histórico inglês.

\footnotetext{
${ }^{1}$ Graduando e bolsista do PET-História desde 2009, com pesquisa individual orientada pela Prof. Dra. Marcella Lopes Guimarães intitulada "Arqueiros Ingleses na Guerra dos Cem Anos: a Transição Militar na Baixa Idade Média".

${ }^{2}$ Uma das mais antigas sociedades literárias de língua inglesa do mundo.
}

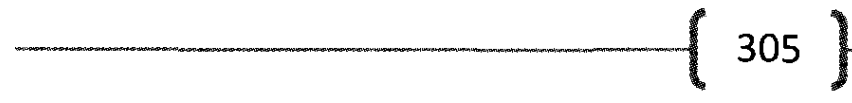


Incluída no calendário da Guerra dos Cem Anos, assim como Crécy (1346) e Poitiers (1356), os ingleses triunfariam sobre os franceses embora estivessem com um exército consideravelmente menor. Agincourt também foi imortalizada na literatura mundial por ninguém menos que William Shakespeare em seu livro Henrique $V$. É sem dúvida um tema de relevância altíssima para ser abordado.

O livro foi estruturado em três partes que têm seus respectivos focos, mas todos organizados em seqüência cronológica. $\mathrm{Na}$ primeira parte "A Estrada para Agincourt", há uma breve descrição do contexto inglês e francês dos séculos XIV e início do $\mathrm{XV}$, bem como dos preparativos para a campanha. A segunda parte "A Campanha de Agincourt" trata da campanha que os ingleses empreenderam na França, desde Harfleur até a batalha de Agincourt em si. A última parte "As Consequências da Batalha" versa sobre o que ocorreu posteriormente a esse confronto e o impacto que a batalha teve nos anos seguintes.

Barker destaca o rei Henrique $\mathrm{V}$ da Inglaterra. Ela tenta, através de documentos e bibliografia a respeito do monarca, traçar um perfil de como ele teria sido e como foi sua liderança para a campanha na Normandia. Resgatando todo seu histórico, a autora mostra um rei influenciado pelas experiências militares vividas; os contatos pessoais - estes que declara imprescindíveis para o sucesso

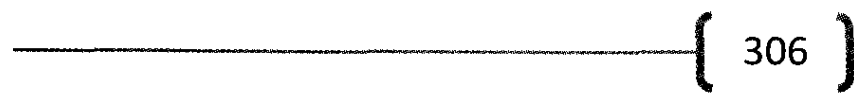


da campanha de Agincourt, tanto com grandes políticos como com os próprios guerreiros que lutavam por seu exército; enfim, como Henrique $\mathrm{V}$ se tornou um ícone, uma inspiração para a hoste inglesa que lutaria pela seqüência da legitimação do poder real inglês sobre a França.

Tem-se também o perfil religioso de Henrique. Como relatado nas fontes, o rei buscava dentro da Bíblia orientações para sua campanha, como no momento em que diz aos sitiados em Harfleur que Deus autorizaria, segundo o livro de Deuteronômio da Bíblia, que saqueassem a cidade se esta não fosse entregue.

A autora faz ainda uma extensa análise para todos os empreendimentos, levantamento de recursos, organização de guerreiros, mercenários, ferreiros, armeiros, cavalos, enfim, tudo o que era necessário para se realizar uma campanha na França. Também se detém no relato do sítio de Harfleur - ponto inicial de um viés prático da campanha. Após isso, só interessa a marcha dos ingleses e tudo o que girava em torno destes até culminar na grande batalha de Agincourt.

Barker analisa o porquê de os ingleses, em um número tão inferior, terem vencido a batalha de forma "simples": eram um exército muito mais coesos, unidos em torno do rei Henrique $\mathrm{V}$ e se sentiam encurralados. Já os franceses estavam subdivididos de forma 
desorganizada em senhores feudais e nobres egoístas que não tinham como idéia principal unirem-se para vencer. Eram numerosos e julgavam a vitória certa - e a matança fácil. Essa desorganização foi o que os levou à derrota.

Mesmo realçando o papel de Henrique $\mathrm{V}$ na batalha, a autora não elabora uma narrativa estritamente política. Ainda sim, é a partir dessa figura que Barker tece uma teia de relações sociais e econômicas, conseguindo quase que contar de forma romântica a história. Embora as fontes tratem majoritariamente da sociedade nobre da época, Barker se permite estudar como agiam todos os membros que compuseram a hoste inglesa e toda a movimentação por trás dela.

É possível identificar ainda as diferenças entre os guerreiros ingleses e franceses, sobretudo focando no aspecto do corpo militar inglês formado em sua grande maioria por arqueiros. Há uma boa análise, embora pudesse ter sido mais explorada, da identidade que caracterizava o exército inglês por sua tática de batalha fundamentada no arco e flecha.

Isso não é um fator que desmereça a obra. Barker fez um trabalho exaustivo de leitura de fontes e análises bibliográficas baseada em diversos autores especialistas no assunto, como Anne 
Curry $^{3}$ e Robert Hardy ${ }^{4}$. É um livro que não relata apenas a batalha de Agincourt em si, pode servir de base para diversas pesquisas dentro do período, e, sobretudo, sobre a Guerra dos Cem Anos.

No Brasil, ainda que o mercado editorial seja tão inconstante a respeito das escolhas por boas traduções, mais sobre uma "História que não nos pertence", potencialmente haveria um público alvo para o tema. Com a difusão de jogos, filmes e romances que tratam de temas históricos e grandes batalhas cresce cada vez mais o interesse a respeito. Assim, a tradução e publicação em menos de quatro anos desde seu original em inglês é um avanço grandíssimo e que pode servir de exemplo para que mais e mais tenhamos contato com diferentes culturas e Histórias, além de dar suporte a quaisquer estudos que estejam relacionados a esses conhecimentos.

${ }^{3}$ Historiadora britânica, especialista na temática envolvendo a Guerra dos Cem Anos, especialmente a batalha de Agincourt.

${ }^{4}$ Ator inglês, também é especialista em estudos sobre o arco-longo inglês e Comandante da Ordem do Império Britânico (Ordem de Cavalaria inglesa fundada em 1917). 